\title{
CARD9 Gene
}

National Cancer Institute

\section{Source}

National Cancer Institute. CARD9 Gene. NCI Thesaurus. Code C131148.

This gene is involved in both innate immunity and apoptosis regulation. 